\title{
ULTRASTRUCTURE OF APOPTOTIC CELLS IN CHICKEN BURSA OF FABRICIUS AFTER GAMMA IRRADIATION
}

\author{
O. EMHMAD ABDOUSLAM ${ }^{1}$, F. OJEDA ${ }^{3}$. M. LEVKUT ' , \\ Z. ŚEVČ́́KOVÁ ${ }^{1}$. I. ŚKARDOVÁ². K. DAXNEROVÁ 4 \\ ${ }^{1}$ Departments of Pathological Anatomy and 'Internal Diseases of Small Animals, \\ University of Veterinary Medicine, Košice, Slovak Republic \\ ${ }^{3}$ Universidad Austral, Instituto de Fisica, P.O.Box 567 Valdivia Chile \\ ${ }^{+}$Department of Cell and Molecular Biology. University P. J. Šafárika, Košice, \\ Slovak Republic
}

Received March 24, 1997

Accepted November 4, 1997

\begin{abstract}
Emhmad Abdouslam O., Ojeda F., Levkut M., Ševčíková Z., Škardová I., Da xnerová K.: Ultrastructure of Apoptotic Cells in Chicken Bursa of Fabricius after Gamma Irradiation. Acta vet. Brno, 1997, 66:155-158.

Ultrastructure of irradiated lymphocytes in bursa of Fabricius was studied. Twenty four chickens were irradiated by gamma rays at a total dose of irradiation $4,5 \mathrm{~Gy}$ and exposure time 12 $\min 24 \mathrm{~s}$. Histological examination showed occurrence of pyknotic cells in bursa in experimental groups. Electron microscopy of the irradiated bursa revealed typical apoptotic morphology such as chromatin condensation, nuclear fragmentation, formation of apoptotic bodies and phagocytosis of apoptotic cells 6 hour after irradiation. The mitochondria appeared to be morphologically intact in the early stages of cell death. Phagocytosis is supposed to be done by resident macrophages which are mainly located in the medulla of the bursa Fabricii. Although bursa Fabricii like other lymphoid organs has been known to be highly sensitive to irradiation. this work shows high scavenger capability of the mononuclear - phagocyte system in bursa of Fabricii.
\end{abstract}

Ultrastructure, apoptotic bodies, phagocytosis

Apoptosis is a form of physiological cell death also referred to as programmed cell death. It is a highly regulated event and plays a role in a number of physiological and pathological processes, such as embryonic development ( $\mathrm{Hinchcliffe} \mathrm{1981),} \mathrm{during} \mathrm{involution} \mathrm{of}$ hormone-dependent organs ( $\mathrm{A}$ li s on and S a r r a f 1992), clonal selection in the immune system and adult tissue maintenance (A rends and Wyllie 1991). It also occurs however, under some pathological conditions, as in tumours (Fesus et al. 1991), some viral infection (B anda et al. 1992; Lam and Vasconcelos 1994), after radiation (Ueda and Shah 1992; Dewey et al 1995) and some haematological diseases which are associated with the production of blood cells ( Yos hida 1993).

Affected cells shrink in volume. lose contact with their neighbours and lose specialised surface elements ( W ylli e 1993). The nuclear events of apoptosis begin with the collapse of the chromatin against nuclear periphery and into one or a few large clumps within the nucleus (Wyllie et al.1980). In many cases the entire nucleus condenses into a single dense ball, whereas in others the chromatin buds outward into small balls, with each ball surrounded by a nuclear envelope ( $E$ arnsh aw 1995).

The aim of this study was the examination of bursa Fabricii by electron microscopy after whole-body gamma-irradiation to study the morphology of changed cells.

\section{Materials and Methods}

Thirty-two $35 \mathrm{~d}$ old chickens (broiler cross-breeds) were divided in four groups of eight birds each. There were three experimental and one control group. The experimental chickens were irradiated by gamma rays (cobalt source 
Chisostat 60 ) at a dose rate of $0.33 \mathrm{~Gy} / \mathrm{min}$. The total dose of irradiation was $4.5 \mathrm{~Gy}$ and exposure time was $12 \mathrm{~min}$ 24 s. SSD (Source-to surface-distance) of 60 Co source was $95 \mathrm{~cm}$. There is a very wide range (1-10 Gy) of irradiation doses reported to induce apoptosis ( A r ra i et al. 1996). The range 4 - 6 Gy is the most often described to cause the most pronounced induction of apoptosis within 6 hours after irradiation (De wey et al. 1995). The chickens were decapitated in groups $1 \mathrm{~h}, 6 \mathrm{~h}$ and $24 \mathrm{~h}$ after irradiation, respectively. Samples of bursa of Fabricius taken for histological examinations were processed by Kon rád et al. (1995). Small pieces of bursa of Fabricius for electron microscopy were collected and immediately immersed in a fixative solution consisting of a mixture of $2.5 \%$ glutaraldehyde and $2.0 \%$ paraformaldehyde in $0.1 \% \mathrm{M}$ cacodylate buffer $(\mathrm{pH} 7.2)$. Samples were postfixed in $0.1 \% \mathrm{OsO}_{4}$, dehydrated by an increasing ethanol series, and embedded in Durcupan. Semi-thin sections 1-2 $\mu \mathrm{m}$ thick were made on a pyramitom LKB, stained with $0.5 \%$ toluidine blue, then evaluated under a light microscope (Carl - Zeiss, Jena). The ultrathin sections were prepared on an ultramicrotome LKB Nova, mounted on copper grids and contrasted with uranyl acetate and lead citrate. The sections were investigated under an electron microscope (JEOL $1200 \mathrm{MX}$ ) with an accelerating voltage of $80 \mathrm{KV}$.

\section{Results}

Light microscopy revealed the occurrence of pyknotic cells in all 24 experimental chickens (Plate V., Fig. 1) but not in controls (Fig. 2). Pyknotic cells occurred both in the follicular medulla and in the follicular cortex, as soon as $1 \mathrm{~h}$ after irradiation. Twenty four $\mathrm{h}$ after irradiation only reticuloepithelial network of follicles without lymphoid cells (Plate VI., Fig. 3) was found. Detailed description of localization and percentage of occurrence of pyknotic cells in bursa of Fabricius was done by Kon rád et al. (1995).

To demonstrate that the found pyknotic cells represent the process of cell death by apoptosis, transmission electron microscopy was used (TEM). As the first stage of apoptosis we observed many shrunken cells whose nuclei contained highly condensed chromatin and occasionally broke up into several fragments in the bursa of irradiated chickens (Plate VII., Fig. 4). These changes were observed in both medullar and cortical parts of follicles. Despite the evident changes in the chromatin organisation, the mitochondria appeared to be morphologically intact in the early stages of cell death (Plate VIII., Fig. 5). Many cells with apoptotic morphology mainly in the medulla appeared to be engulfed by neighbouring phagocytic cells $6 \mathrm{~h}$ after irradiation (Plate IX., Fig. 6). Furthemore, TEM observation displayed many roundish bodies after nuclear fragmentation in the bursa of the irradiated chickens (Plate X., Fig. 7). These bodies not only varied in size, but were also considerably smaller than lymphocytes, indicating that these bodies represent apoptotic bodies. After 24 hours only a few apoptotic lymphocytes were observed mainly in the cortex of the bursa of Fabricii.

\section{Discussion}

Although by Konrád et al. (1995) there were no pyknotic cells observed in control group, a low percentage of pyknotic cells as a form of apoptosis could be observed in unirradiated chicken bursa of Fabricius ( A r a i et al. 1996). It is a normal process of clonal selection of lymphocytes in this organ.

The increasing occurrence of pyknotic cells is known to be detected after irradiation of this organ (Maruyama and Feola 1987). The present study confirmed the marked increase of pyknotic cells in bursa of irradiated chickens and clarified the ultrastructural characteristic of the pyknotic cells. Cell death of bursa lymphocytes revealed typical morphology for apoptosis such as shrinkage in volume, chromatin condensation, nuclear fragmentation followed by formation of apoptotic bodies (Ueda and Shah 1994). Electronogram showed that most of apoptotic cells are engulfed by macrophages after death. Early phagocyting process is supposed to be done by resident macrophages mainly in the medulla of bursa. It is known that the cortex of bursa contains densely populated small lymphocytes and lymphoblasts, whereas lymphocyte population is sparsier in the medulla 
contains also macrophages and dendritic reticular cells (B et ti et al. 1991). Conventional electron microscopy, such as that used here, is usually unable to identify the type of cells with apoptotic morphology. However, it seems likely that the majority of the apoptotic cells observed in bursal follicle are lymphocytes, since nonlymphoid cells located in lymphoid tissue are known to be much more radioresistent than lymphoid cells and to be little affected by radiation used in this study (Maruyuama and Feola 1987). Location of macrophages in the medulla can explain that medullar reticuloendothelial network contains less apoptotic lymphoid cells than that in the cortex, indicating that phagocyting capacity of macrophages is large. The rapid and nearly complete removal of the apoptotic cells suggests that the chicken bursa of Fabricius possesses effective cellular systems by which apoptotic cells are recognized and removed rapidly. Although bursa Fabricii like other lymphoid organs has been known to be highly sensitive to radiation this work shows high scavenger capability of the mononuclear - phagocyte system in bursa of Fabricii.

The present study demonstrated electron microscopically changes of apoptotic cells after irradiation of bursa Fabricii. The study also showed higher radioresistance of macrophages as compared to lymphoid cells. Phagocytosis of dead cells is believed to be done by resident macrophages which are mainly located in the medulla of bursa Fabricii.

\section{Ultraštruktúra apoptóznych buniek burzy Fabricii u kurčiat po gama ožiarení}

Ultraštruktúra ožiarených lymfocytov burzy Fabricii bola sledovaná u 24 kurčiat po ožiarení gama, pri celkovej dávke 4,5 Gy a expozícii 12 min., 24 s. Histologickým vyšetrením sme v experimentálnej skupine dokázali pyknotické bunky v burze Fabricii. Pomocou elektrónovej mikroskopie sme overili v burze typickú apoptóznu morfológiu, ako napríklad kondenzáciu chromatínu, fragmentáciu, tvorbu apoptóznych teliesok a fagocytózu apoptóznych buniek $6 \mathrm{~h}$ po ožiarení.

Fagocytóza pravdepodobne prebieha prostredníctvom rezidentných makrofágov, ktoré sú lokalizované najmä v dreni burzy Fabricii.

Hoci burza Fabricii je podobne ako ostatné lymfoidné orgány vysoko senzitívna voči ožiareniu, potvrdzuje táto práca vysokú čistiacu schopnost̉ jej mononukleárneho fagocytárneho systému.

\section{References}

ALISON, M. R., SARRAF, C. E. 1992: Apoptosis a gene directed programme of cell death. J. Roy. Coll. Phys. Lond. 26:25-35

ARAI, S.. KOWADA, T., TAKEHANA, K., MIYOSHI, K., NAKANISHI, Y. H. HAYASHI, M. 1996: Apoptosis in the Chicken Bursa of Fabricius Induced by X-Irradiation. J. Vet. Med. Sci.: 58:1001-1006

ARENDS. M. J., WYLLIE, A. H. 1991: Apoptosis: mechanisms and roles in pathology. Int. Rev. Exp. Pathol. 32: 223-254

BANDA, N. K., BERNIER, J., KURAHARA, D. K., KURRLE, R., HAIGWOOD, N., SEKALY, R. P., FINKEL, T. H. 1992: Crosslinking CD4 by human immunodeficiency virus gp 120 primes T cells for activation-induced apoptosis. J. Exp. Med. 176: 1099-1106

BETTI. F. WORSMAN,T. U., De FARIA. F. P., SESSO, A. 1991: Development of the cloacal bursa in the domestic fowl. II. A quantitative and fine structural analysis of the follicular cortex and medulla. J. Submicrosc. Cytol. Pathol. 23: 613-628

DEWEY, W.C., LING, C. C., MEYN, R. E. 1995: Radiation-induced apoptosis: relevance to radiotherapy. Int. J. Radiation Oncology Biol. Phys., 33: 131-134

EARNSHAW, W. C. 1995: Nuclear changes in apoptosis. Current Opinion In Cell Biology, 7: 337-343

FESUS, L.. DAVIES, P. J. A., PIACENTINI, M. 1995: Molecular mechanism in the program of cell death by apoptosis. Eur. J. Cell Biol. 56: 170-177

HINCHCLIFFE, J. F., 1981: Cell death in embryogenesis. In Bowen, I. D., Lockshin, R. A. ed, Cell Death in Biology and Pathology. Chapman and Hall, London, pp. 35-78 
KONRÁD, V., ŠKARDOVÁ, I., OJEDA,F., LEVKUT, M., PROSBOVÁ, M. 1995: The apoptosis of lymphocytes in chicken bursa of Fabricius after gamma irradiation. Folia Veterinaria 39: 97-99

LAM, K. M., VASCONCELOS, A. C. 1994: Newcastle disease virus induced apoptosis in peripheral blood lymphocytes. Vet. Immunol. Immunopathol. 44: 45-56

MARUYAMA, Y., FEOLA, J. M. 1987: Relative radiosensitivities of the thymus, spleen, and lymphohemopoetic systems. Adv. Radiat. Biol. 12: 1-82

REYNOLDS, E. S. 1963: The use of lead citrate at high pH as an electron - opaque stain in electron microscopy. J. Cell Biol. 17: 208-212

UEDA, N., SHAH, S. V. 1994: Apoptosis. J. Lab. Clin. Med. 124: 169-177

WATSON, M., 1958: Staining of tissue sections for electron microscopy with heavy metals. J. Biophys. Biochem. Cytol. 4: 475-478

WYLLIE, A. H. 1993: Apoptosis. Br. J. Cancer 67: 205-208

WYLLIE, A. H. 1980: Glucocorticoid-induced thymocyte apoptosis is associated with endogenous endonuclease activation. Nature 284: 555-556

YOSHIDA, Y. 1993: Hypothesis: apoptosis may be the mechanism responsible for the premature intramedullary cell death in the myelodysplastic syndrome. Leukemia 7: 144-146

Address for correspondence:

O. E. Abdouslam

Department of Pathological Anatomy

University of Veterinary Medicine

Komenského 73

04181 Košice

Slovak Republic

Phone: (421) 95633211 
Plate V.

Abdouslam O. E. et al.: Ultrastructure... pp. 155-158

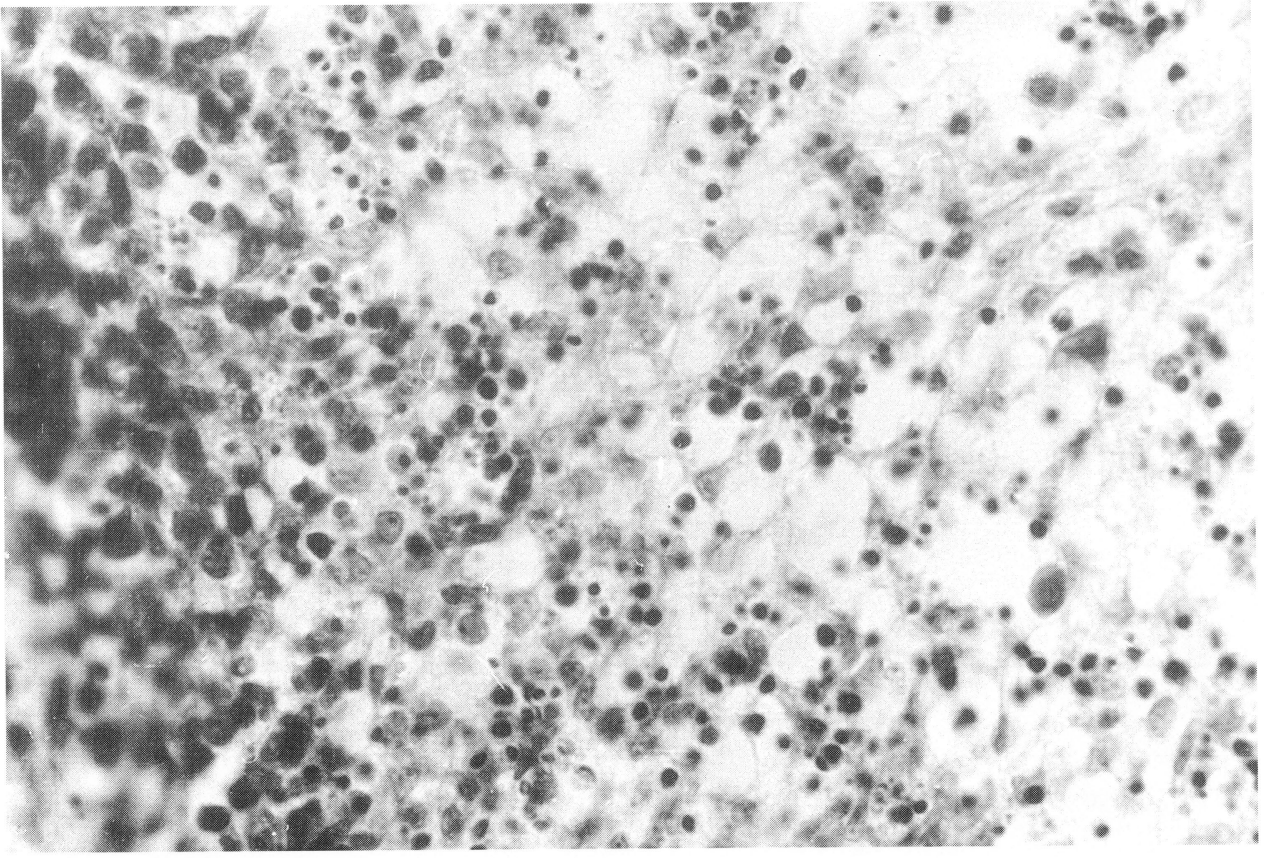

Fig 1. Six hours after irradiation, pyknosis of lymphoid cells in medulla of follicles was found. HE, $\times 800$

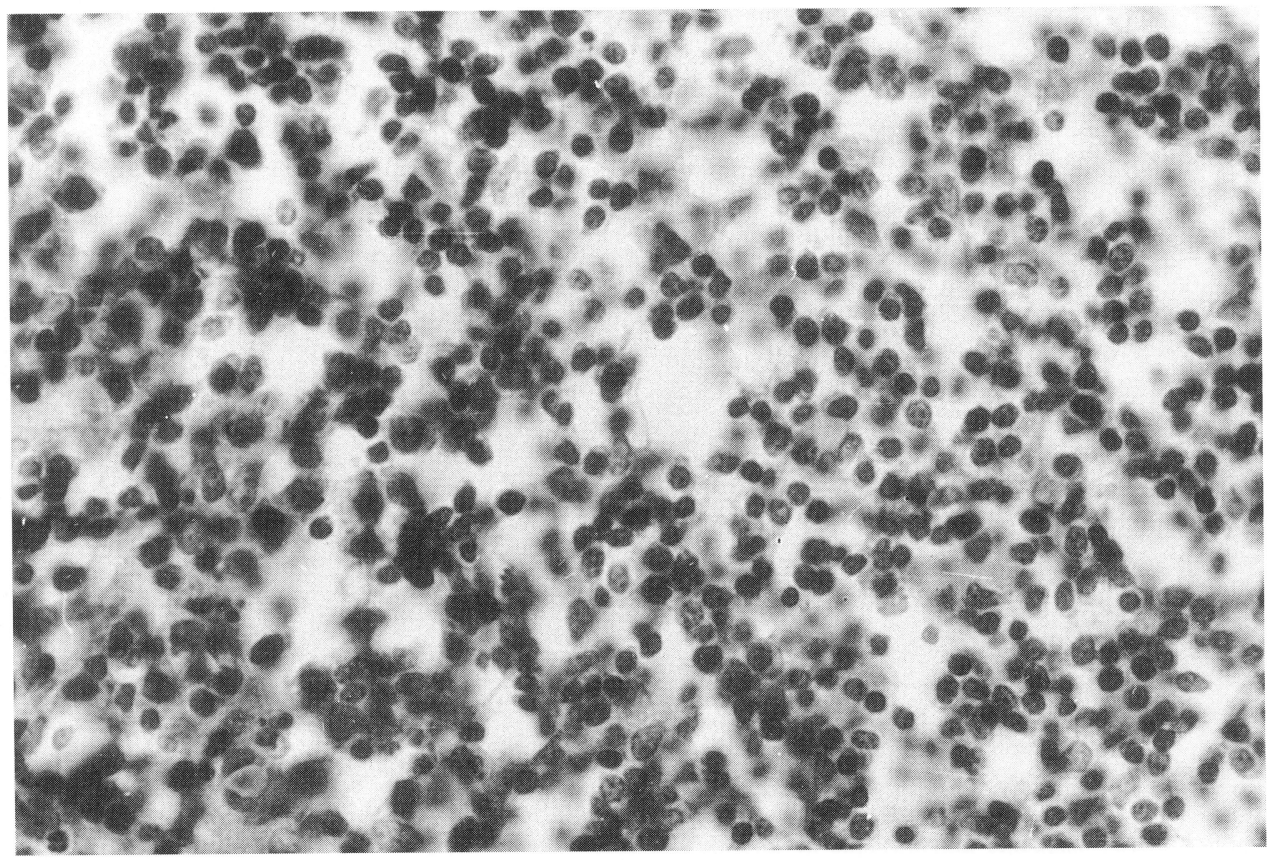

Fig. 2. Normal lymphoid cells in the follicle of control chickens. HE, $\times 200$ 
Plate VI.

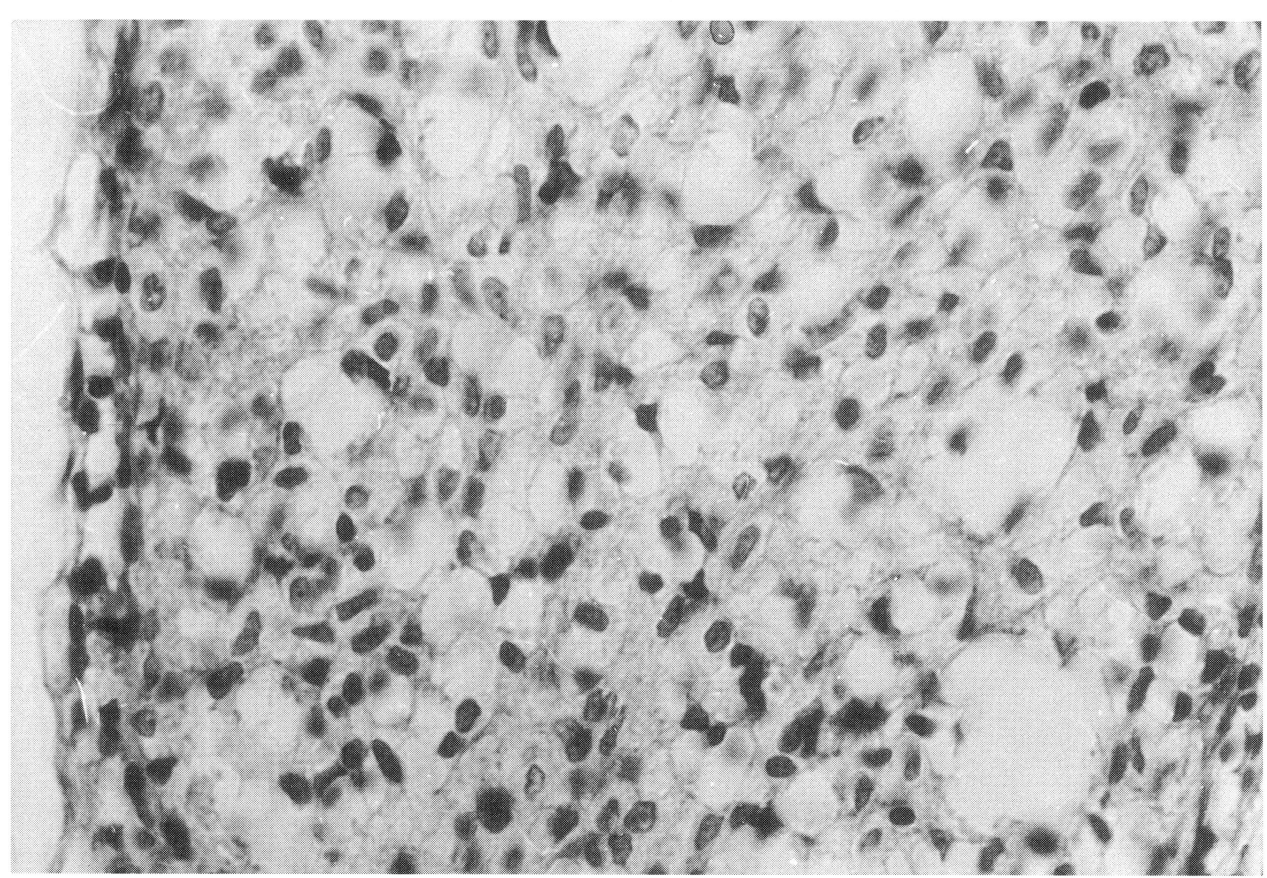

Fig. 3. Twenty-four hours after irradiation, no medullary lymphocytes remained in the chicken bursa of Fabricius, and in the cortex only a few pyknotic lymphocytes were found. HE, $\times 800$ 


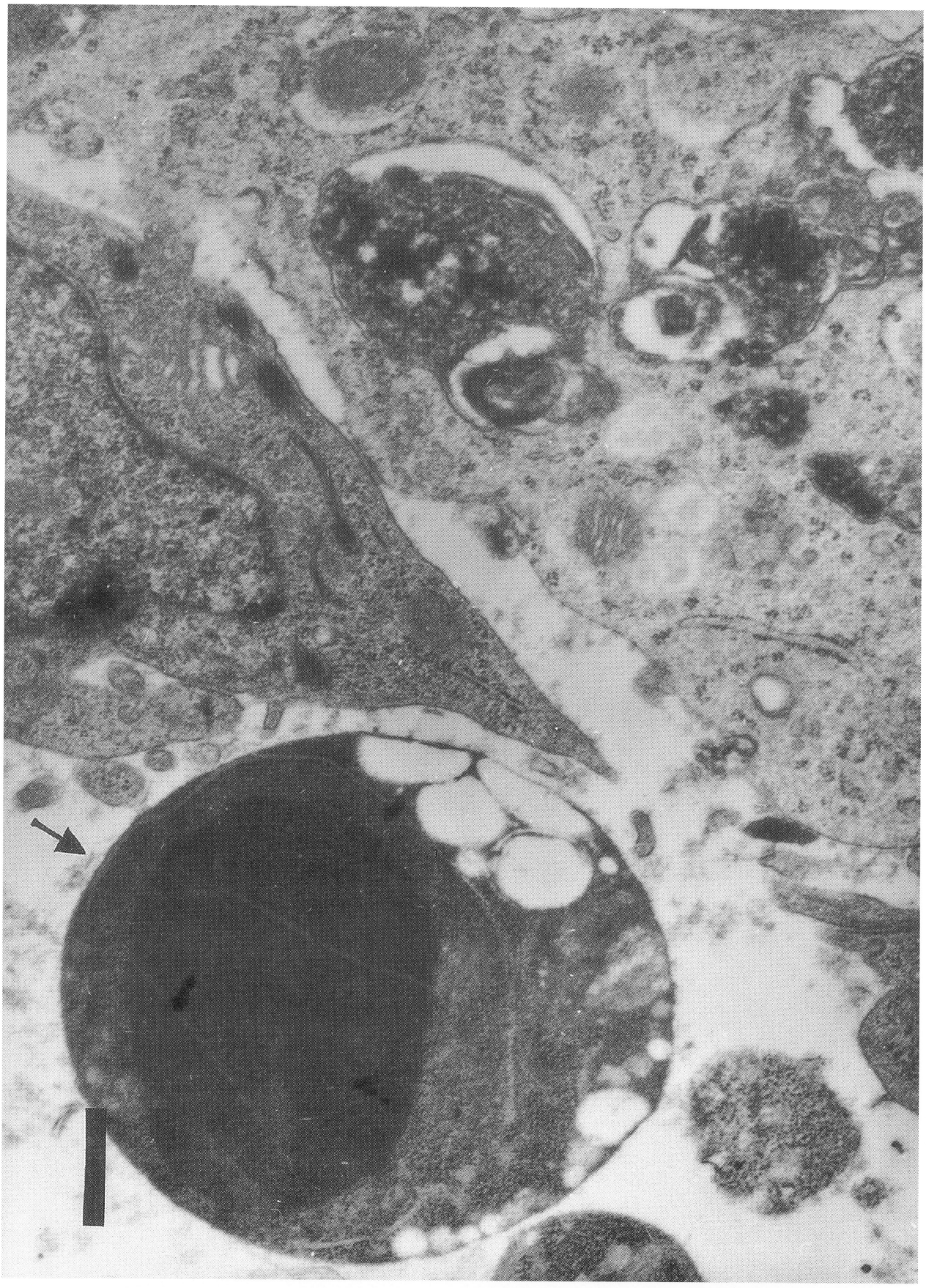

Fig. 4. Transmission electron micrograph of the bursa of Fabricius in experimental chickens. Arrow shows shrunken cell with highly condensed chromatin. (Bar $500 \mathrm{~nm}$ ). 
Plate VIII.

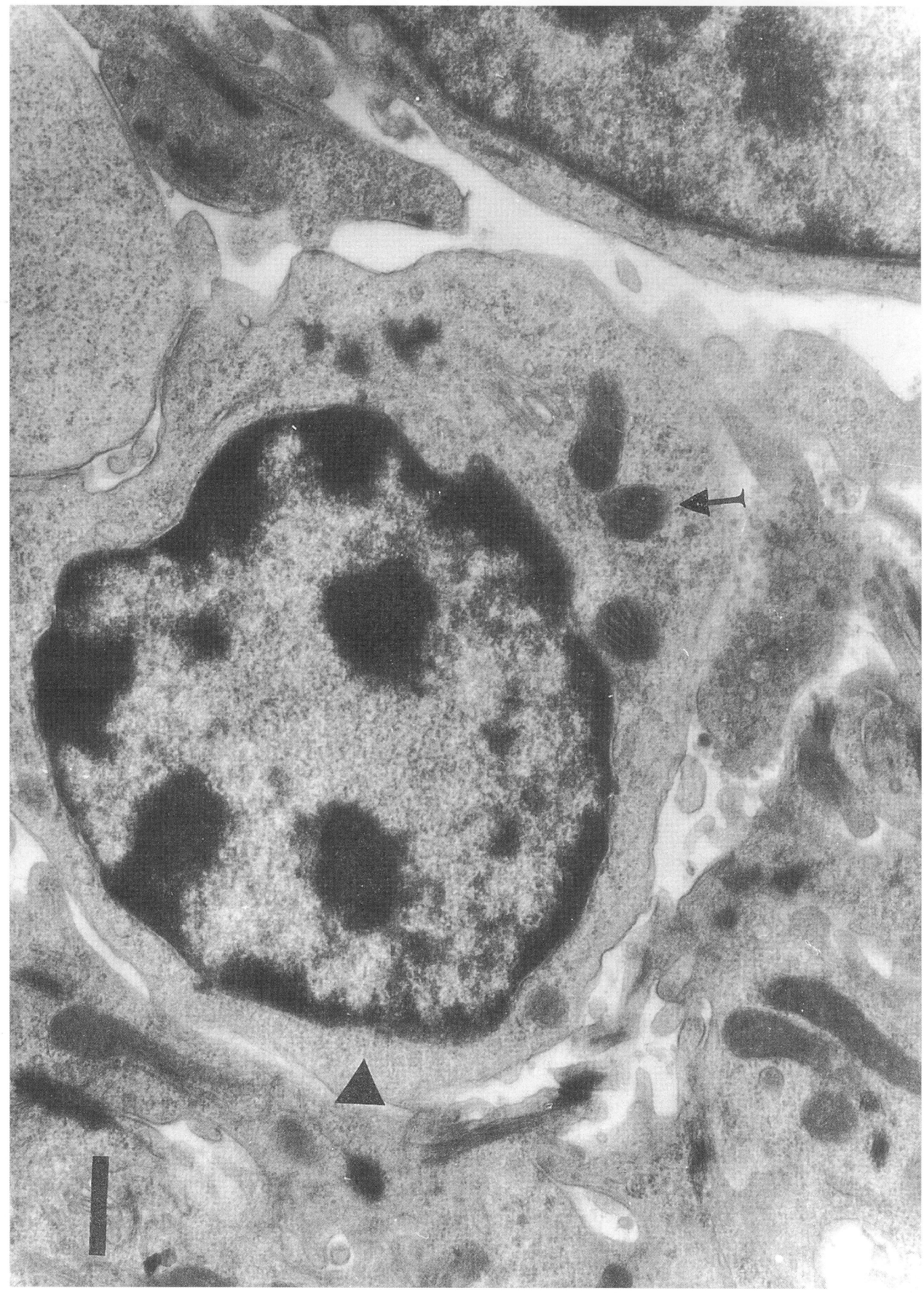

Fig 5. Transmission electron micrograph of the bursa of Fabricius in experimental chickens. Despite the evident changes in the chromatin organisation indicated by arrow head intact mitochondria are still visible (arrow) (Bar $500 \mathrm{~nm})$. 
Plate IX.

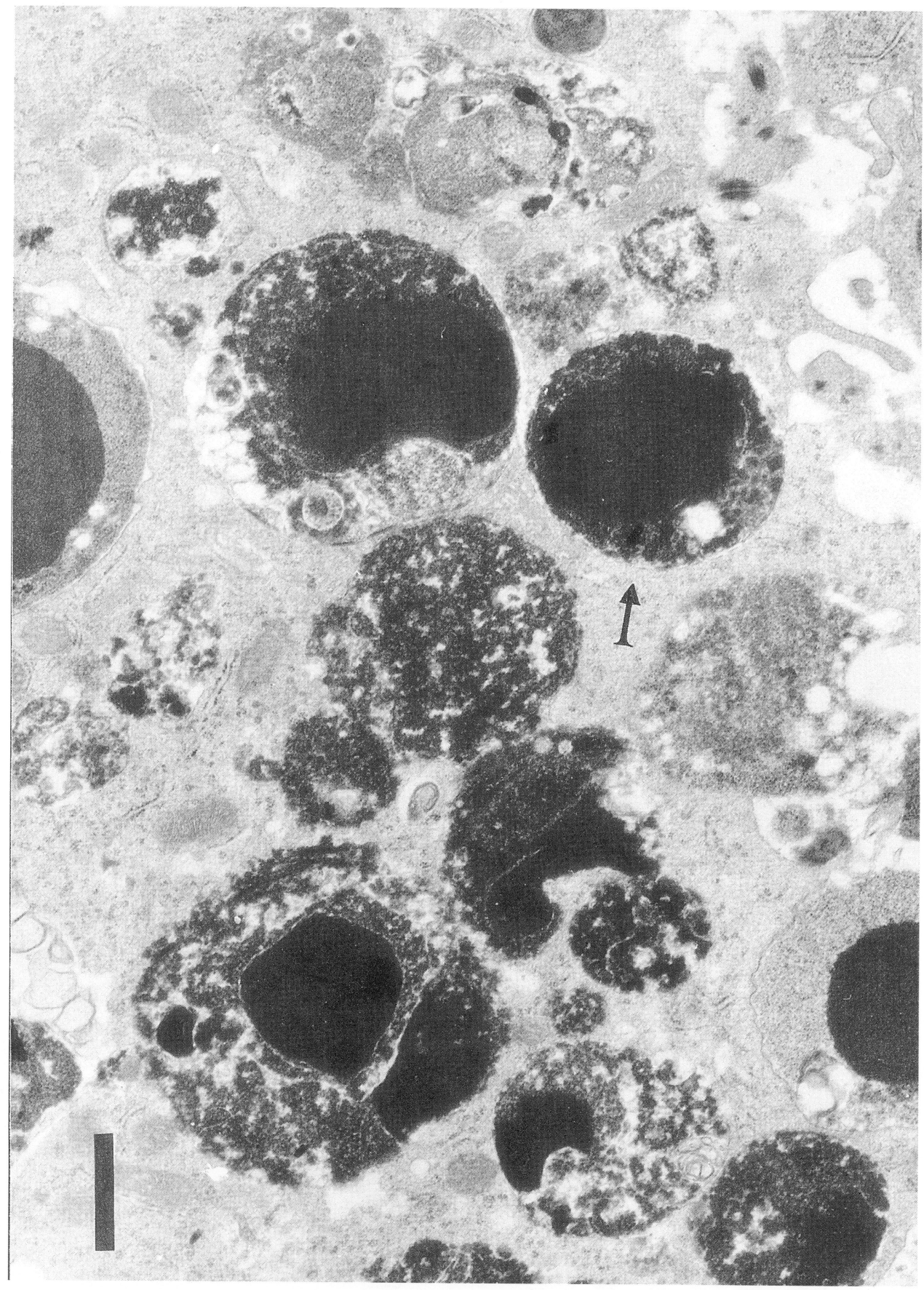

Fig. 6. Transmission electron micrograph of the bursa of Fabricius in experimental chickens. Arrow shows one of many apoptotic cells which are engulfed by phagocytic cell mainly in the medulla, $6 \mathrm{~h}$ after irradiation. (Bar $1 \mu \mathrm{m})$. 


\section{Plate X.}

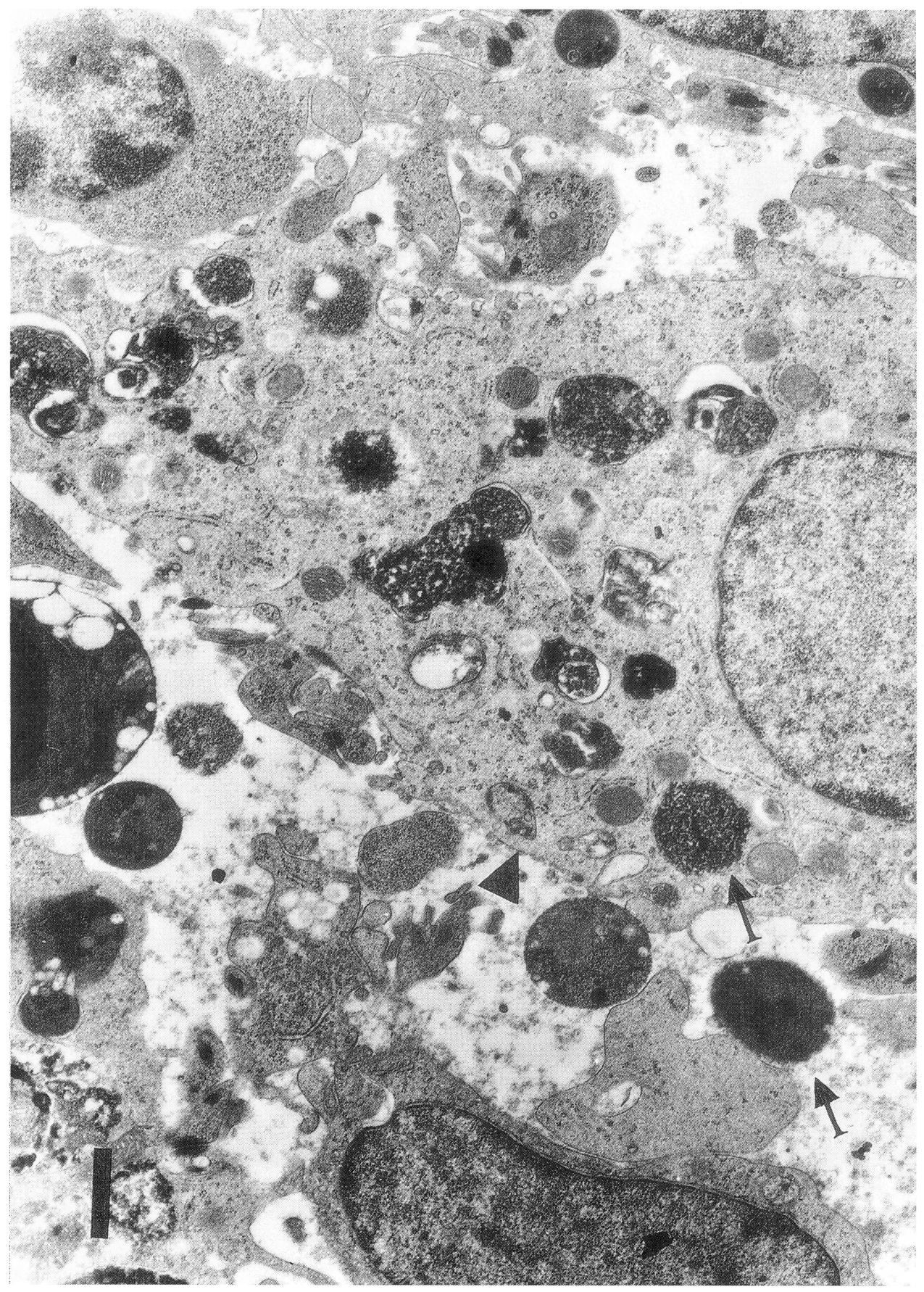

Fig. 7. Transmission electron micrograph of the bursa of Fabricius in experimental chickens. Arrows show apoptotic body before and after phagocytosis. The arrow head shows cytoplasmic membrane of the macrophage. $($ Bar $1 \mu \mathrm{m})$. 